\title{
Nota and Require: The Oldest Western Annotation Symbols and Their Dissemination in the Early Middle Ages
}

\author{
EVINA STEINOVÁ ${ }^{1}$
}

Apart from glosses, illuminations and diagrams, the margins of medieval manuscripts commonly feature annotation symbols - signs that were used to perform routine operations with the text or provided a framework for its use. ${ }^{2}$ One annotation symbol familiar to anyone who has studied a medieval manuscript is the nota monogram, which was regularly used in the Middle Ages to mark points of interest - literally admonishing the reader to pay attention to a particular passage. Another common medieval annotation sign, the r-shaped require siglum, was used to mark passages in need of checking because they contained an error or corruption. ${ }^{3}$ Over the past four years, I have systematically examined the use of these and other annotation symbols in early medieval Latin manuscripts. Altogether, I counted almost eighty different graphic signs used for the purpose of annotation or described as such in medieval written sources. ${ }^{4}$ In this paper, I focus on two of them - the nota monogram and the require siglum. I show that they both originated as elements of a particular package of late antique Christian annotation practices. From humble origins in Late Antiquity, the nota and the require rose to become the dominant forms of annotation symbols in the early medieval Latin West, their popularity surpassing that of other signs that came into being in the same period and context, or that had an older and nobler pedigree. The prestige that the two signs attained by the Carolingian period is not self-evident, but rather points to the influence that specific late antique Christian practices had on early medieval intellectual life.

\section{Carolingian zenith}

\footnotetext{
${ }^{1}$ I would like to thank Anna Dorofeeva, Jesse Keskiaho and Cinzia Grifoni for valuable comments on an earlier draft of this paper.

${ }^{2}$ Good introductions to the topic of annotation symbols are Malcolm Beckwith Parkes, Pause and Effect: An Introduction to the History of Punctuation in the West (Aldershot: Scolar, 1992); Adolfo Tura, 'Essai sur les marginalia en tant que pratique et documents', in Scientia in margine: études sur les Marginalia dans les manuscrits scientifiques du Moyen Âge à la Renaissance, ed. by Danielle Jacquart and Charles S. F. Burnett, Sciences historiques et philologiques. Hautes études médiévales et modernes, 88 (Genève: Droz, 2005), pp. 261-387 (pp. 274-97); Evina Steinová, 'Psalmos, Notas, Cantus: The Meanings of Nota in the Carolingian Period', Speculum, 90.2 (2015), 424-57.

${ }^{3}$ How the r-shaped symbol should be understood was established by Wilhelm Wattenbach, Das Schriftwesen Im Mittelalter. (Graz: Akademische Druck- u. V.-A, 1958), p. 336. Lindsay opts for reading it both as require and requirendum; see Wallace Martin Lindsay, Palaeographia Latina (London: St. Andrews University Press, 1923), II, pp. 12-13.

4 The results of this research are presented in Evina Steinová, 'Notam Superponere Studui: The Use of Technical Signs in the Early Middle Ages’ (unpublished Ph.D. dissertation, Utrecht University, 2016). I am currently preparing a monograph on the subject for publication with Brepols.
} 
Turning the leaves of Carolingian manuscripts, one can hardly miss the signs and sigla that appear commonly in their margins..$^{5}$ A palaeographer trying to uncover the pattern of their use will sooner or later discover that some symbols occur in the margins more regularly and consistently than others, and that two of them are particularly prominent - the nota monogram and the require siglum. This hunch can be supported by a probe such as the one provided by the 152 manuscripts now preserved in the Bayerische Staatsbibliothek in Munich that were produced in the eighth and the ninth centuries in Bavaria, and represent the scribal practices of early medieval Freising and Regensburg. ${ }^{6}$ The nota can be found in 57 and the require in 85 of the 152 manuscripts, corresponding to $37.5 \%$ and $56 \%$ of the corpus respectively. Only two signs can be found in more codices from this set: the cross (102 mss.) - which, however, does not seem to have been used with a single meaning nor consistently and the S-shaped citation mark (87 mss.), which, as will be discussed later, should be considered a sibling of nota and require. The number of manuscripts among the 152 Bavarian codices kept at Bayerische Staatsbibliothek that contain at least one page marked with the most common annotation symbols (the chresimon, cross, cryphia, insular citation marks, nota, require, S-shaped citation mark, trigon and retei signs) is shown in Fig. $1 .^{7}$

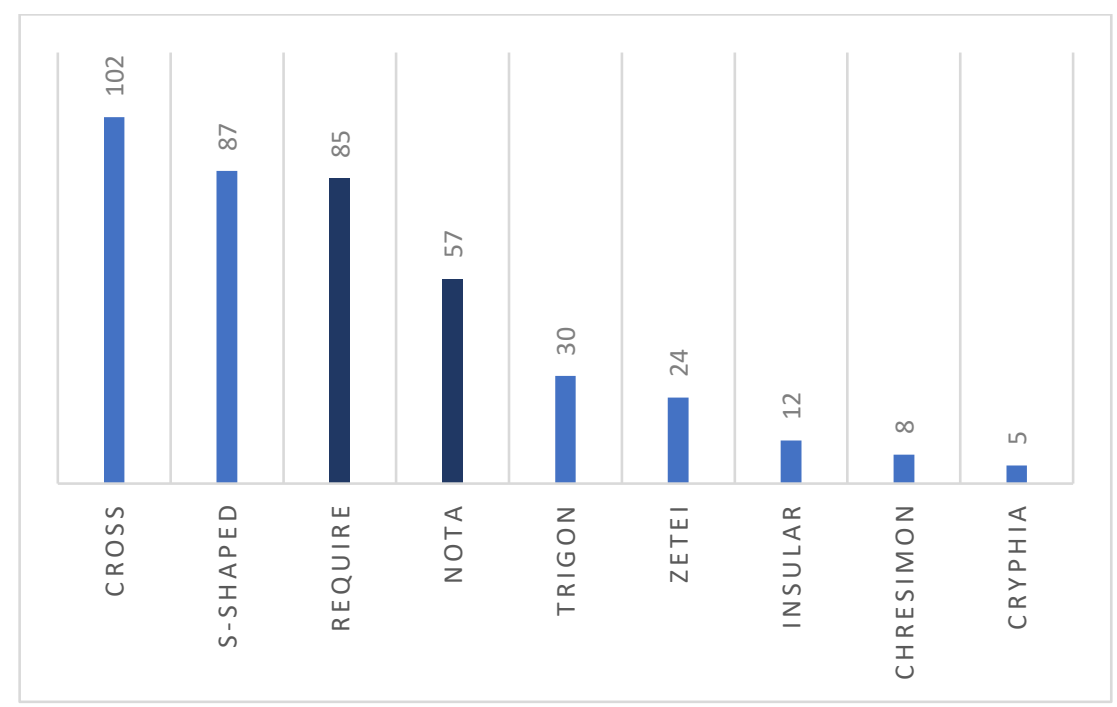

\footnotetext{
${ }^{5}$ Exactly how common the use of annotation symbols was can be guessed from case-studies of particular manuscript corpora. In the Bavarian corpus I discuss below, only thirteen out of 152 examined manuscripts contained no annotation symbols, meaning that more than $90 \%$ of eighth and ninth-century manuscripts produced and preserved in Bavaria were annotated in this manner. If we consider only those manuscripts that contain at least a certain number of pages containing signs, say $10 \%$, the proportion of manuscripts equipped with annotation symbols is roughly two thirds of this corpus; see Steinová, 'Notam Superponere Studu', p. 239. If we take these ratios as representative of Carolingian manuscripts generally, it is clear that the usage of annotation symbols was widespread and well-established.

${ }^{6}$ These manuscripts were described in Bernhard Bischoff, Die südostdeutschen Schreibschulen und Bibliotheken in der Karolingerzeit, Sammlung bibliothekswissenschaftlicher Arbeiten, 49, 2 vols (Wiesbaden: Harrassowitz, 1940-80); and Katharina Bierbrauer, Die vorkarolingischen und karolingischen Handschriften der Bayerischen Staatsbibliothek, Katalog der illuminierten Handschriften der Bayerischen Staatsbibliothek in München, 1 (Munich: Reichert, 1990), as well as in catalogues published by the Bayerische Staatsbibliothek. The corpus is described in Steinová, 'Notam Superponere Studu', pp. 222-25. While not a perfect proxy for Carolingian annotation practices, the Bavarian corpus is nevertheless a useful approximation, especially given the substantial rate of preservation of early medieval manuscripts from Freising and Regensburg, and the fact that they were preserved in the same institutions that produced them into the modern period.

7 The manuscript data visualized in Fig. 1 were analyzed in detail in Steinová, 'Notam Superponere Studu’, pp. $236-51$.
} 
Fig. 1: Number of manuscripts from the Bavarian corpus containing specific annotation symbols

The nota and require were not only among the annotation symbols used most regularly in early medieval Bavaria, but also among those employed most consistently. This can be demonstrated by calculating the average number of pages annotated with a given sign in manuscripts from the set that contain at least one annotated page (i.e. the 57 and $85 \mathrm{mss}$. for the nota and the require respectively), which indicates whether the users of these signs tended to deploy them sporadically or systematically. The averages for the three signs used most commonly in Bavaria for marking passages of interest (light) and for textual errors (dark) are shown in Fig. 2. As these averages show, annotators in early medieval Bavaria used nota monograms more systematically than other signs for marking passages of interest: on average, nota monograms appear on twenty-nine pages in a manuscript. Similarly, not only were require sigla used in many manuscripts, but they were used more consistently than other signs for textual errors: on average, each manuscript contains eleven of them. ${ }^{8}$

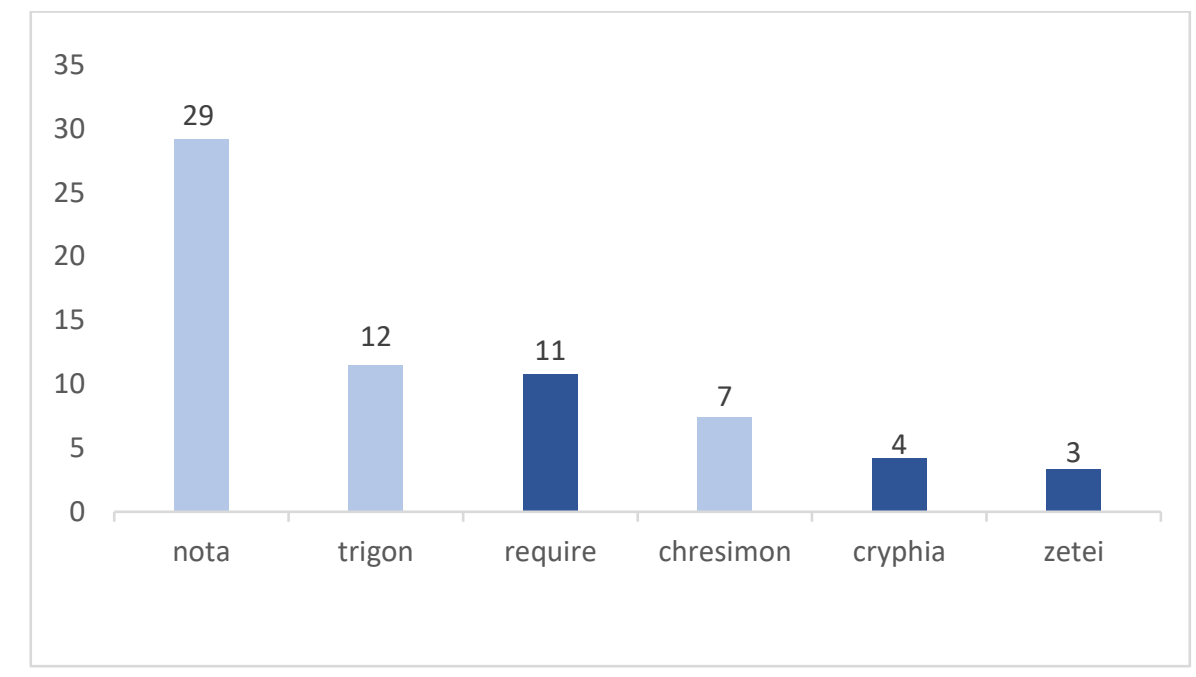

Fig. 2: Average number of pages per manuscript containing attention (orange) or correction (blue) signs

Finally, while those Bavarian manuscripts with the fewest annotation symbols may contain only one or two nota/ require signs - a trace of a casual reader whose engagement with the book may have been superficial - the manuscripts with the most annotations have dense, systematic marginalia, which suggest the work of an annotator with a clear purpose. The latter codices reveal programmatic readers, that is those, who employed nota and require signs to perform specific forms of reading. Thus, some early medieval Bavarian books were used for focused study, their readers deploying nota monograms to examine certain topics. ${ }^{9}$ Other readers made a conscious effort to mark passages that required

\footnotetext{
${ }^{8}$ Nevertheless, one can observe an inverse pattern to the distribution of nota and require. The former were used in fewer manuscripts but in greater numbers, while the latter appear in more manuscripts but in fewer numbers.

9 This may be the case with Munich, Bayerische Staatsbibliothek, Clm 9515 ( $9^{\text {th }}$ century, 1/4, Regensburg), a manuscript of Gregory's Homiliae in evangelia, which contains 142 pages marked with nota monograms. In Freising, a ninth-century reader went systematically through two manuscripts of Gregory's Moralia in Iob, Munich, Bayerische Staatsbibliothek, Clm 6252 ( $9^{\text {th }}$ century 2/4, Freising) and Munich, Bayerische Staatsbibliothek, Clm 6274 ( $9^{\text {th }}$ century, med., Freising), equipping them with over 100 nota monograms each. A third Freising copy of Gregory’s Moralia, Munich, Bayerische Staatsbibliothek, Clm 6279 ( $9^{\text {th }}$ century, 4/4, Freising), may have been annotated by the same reader.
} 
checking against a different codex, perhaps as preparatory work for a collation. ${ }^{10}$ While other annotation symbols could also be used programmatically, this was rarely the case in early medieval Bavaria. S-shaped flourishes, nota and require took precedence over other signs, another indication of their prominence in regional annotation practices.

The data provided by the Bavarian corpus shows that Bavarian scribes regularly employed only a small number of annotation symbols from a larger repertoire. Both the nota and the require belong to this core group. Annotators tended to use them consistently, persistently, and preferred them for programmatic reading. The extent and consistency of use of these two signs indicate, moreover, that their meaning and function were well understood by their users, as well as by those who perused the annotated manuscripts. I did not detect any ambiguity in the usage of nota and require, nor a drive to replace them, in the Bavarian set. This is in contrast with other signs such as the triangle of dots (trigon, Figs. 1 and 2), whose function seems never to have been well-defined; or the insular citation markers (insular in Fig. 1), which were erased and replaced with S-shaped flourishes in several manuscripts. ${ }^{11}$ The lack of ambiguity of usage strengthens the impression that the two annotation symbols belonged to a standard set of scribal practices in the Carolingian period.

Two observations should be added here, based both on the Bavarian corpus and on an examination of Carolingian manuscripts from other regions. First, the nota and require were used to perform two tasks most commonly carried out by means of signs in the early Middle Ages: the marking of passages of interest (done using what I shall term attention signs) and of text in need of correction (done using what I shall term correction signs). Potentially, both tasks could be carried out without resorting to signs, for example by underlining, framing or expunction. In practice, however, early medieval manuscript users relied on a limited set of conventions dictated by tradition and the custom of their scribal community. Interesting passages were, therefore, marked almost exclusively using signs, which were also the popular (if not the only) option for indicating textual errors (which probably explains their lower numbers in manuscripts overall). ${ }^{12}$ Moreover, the nota and require represent only two of several established conventions for annotation symbols. ${ }^{13}$ In Bavaria, passages of interest were also marked with a sign that resembles a triangle of dots (the trigon) and by the chi-rho monogram (the chresimon), and lines in need of correction could also be marked with a z-shaped siglum (the zeter) or

\footnotetext{
10 This may be the case with Munich, Bayerische Staatsbibliothek, Clm 14200, a copy of Jerome's commentary on Ezekiel, which was corrected using the require on 69 pages. The manuscript is digitized at: http://daten.digitale-

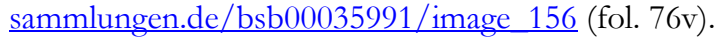

11 A Bavarian example can be found in Munich, Bayerische Staatsbibliothek, Clm 6316 ( $8^{\text {th }}$ century, 2/2, Freising), digitized at: http://daten.digitale-sammlungen.de/bsb00047260/image 216 (fol. 107v). For more examples from other regions, see Evina Steinová, 'The Rise of the Quotation Sign in the Latin West and the Changing Modes of Reading between the Sixth and the Ninth Centuries'.

12 Various methods of manuscript correction are described in Wattenbach, pp. 317-44; Lindsay, II, pp. 10-15.

${ }^{13}$ It should be, moreover, added that while require was primarily a correction sign, it was occasionally also used in other capacities, as I was reminded by my colleague Jesse Keskiaho. For example, a ninth-century annotator of Verona, Biblioteca Capitolare, MS XXVIII (after 420, Italy, CLA IV 491) identified by the CLA as Pacificus of Verona used require in a capacity of attention sign. See also David Ganz, 'The Merovingian Library of Corbie', in Columbanus and Merovingian Monasticism, ed. by Howard B. Clarke and Mary Brennan, BAR International Series, 113 (Oxford: British Archeological Reports, 1981), pp. 153-72 (p. 154).
} 
with the cryphia $(\bullet)$ described by Isidore of Seville. ${ }^{14}$ However, the nota and require were the preferred forms of attention and correction sign respectively, occurring in more manuscripts than any other such sign and with a greater degree of consistency. ${ }^{15}$ The preference was rarely absolute, as conventions were allowed to co-exist due both to local variance and to a degree of idiosyncrasy, so that different symbols encoding the same procedure can occasionally be found side by side in the same manuscript. ${ }^{16}$ Nevertheless, most early medieval annotators evince a definite preference for a particular convention, whether in a given manuscript or across multiple codices. ${ }^{17}$ Innovation and eccentricity were rare, usually indicating a scholarly project or a specialised context of use. ${ }^{18}$

\section{Late antique origins}

Early medieval usage patterns for the nota and require signs suggest that both were well-established in the Latin West by the ninth century. But that this was not always the case becomes clear once we look at a different corpus: ancient Greek and Latin papyri from Egypt, which reflect scribal practices between the $3^{\text {rd }}$ century BCE and the $3^{\text {rd }}$ century CE. As in the early medieval West, a rich array of annotation symbols appear in these papyri, as was shown by Kathleen McNamee. ${ }^{19}$ However, the nota and the require are absent (as is the S-shaped flourish). It could be argued that this has to do with the nature of the material, which comes from Egypt rather than the Latin West and includes

${ }^{14}$ Isid. Etym. 1.21.10: Cryphia, circuli pars inferior cum puncto, ponitur in his locis, ubi quaestio dura et obscura aperiri vel solvi non potuit; Wallace Martin Lindsay, Etymologiarum sive Originum libri XX, 2 vols (Oxford: Clarendon Press, 1911), I.

15 The nota and require, together with the S-shaped flourish, were therefore the only annotation symbols that appeared consistently and persistently in manuscripts across the entire Bavarian corpus. By contrast, the trigon and the z-shaped signs appear more commonly in pre-800 manuscripts, suggesting that they reflect a pre-Carolingian substrate in Bavaria, while chresimon, cryphia and frontis appear only in a cluster of late manuscripts.

${ }^{16}$ In St. Gallen, Stiftsbibliothek, MS 48 ( $9^{\text {th }}$ century, 2/4 or med., possibly northern Italy), both a require and a z-shaped sign mark an error on p. 365, at: http://www.e-codices.unifr.ch/en/csg/0048/365/0/Sequence-255. In Bern, Burgerbibliothek, MS 363 ( $9^{\text {th }}$ century, $3 / 4$, perhaps St. Gallen) the same two annotation symbols were used to mark lines in need of correction on fols. $17 \mathrm{v}$ and $80 \mathrm{v}$; and in Paris, Bibliothèque de l'Arsenal, MS 599 ( $8^{\text {th }}$ century, ex., Charlemagne's court), a z-shaped siglum is found on fol. $65 \mathrm{r}$ next to an error also marked by a series of triga, at: http://gallica.bnf.fr/ark:/12148/btv1b84559055/f133.item.

${ }_{17}$ The best testament to the general stability of scribal annotation practices are the personal practices of notable Carolingian scholars. The predilection of Lupus of Ferrières for cryphia and an angular form of nota resembling a staircase was documented in Charles Henry Beeson, Lupus of Ferrières as Scribe and Text Critic: A Study of His Autograph Copy of Cicero's De Oratore, Publications of the Mediaeval Academy of America, 4 (Cambridge, MA: Mediaeval Academy of America, 1930), pp. 27-29. Florus of Lyon developed a complex system of annotation symbols including paragraphi and positurae for excerption; see Célestin Charlier, 'Les manuscrits personnels de Florus de Lyon et son activité littéraire', in Mélanges E. Podechard (Lyon, 1945), pp. 71-85 (reprinted in Revue Bénédictine 119.2, 2009, 252-69), and more recently Pierre ChambertProtat, 'Florus de Lyon, lecteur des Pères. Documentation et travaux patristiques dans l'Eglise de Lyon au neuvième siècle' (unpublished Ph.D. dissertation, Paris, EPHE, 2015).

${ }^{18}$ See, for example, the annotation symbols in the manuscripts of the Liber glossarum; Franck Cinato, 'Que nous apprennent les écritures des plus anciens témoins du Liber Glossarum sur l'archétype?’, Dossiers d'HEL, 2016, 59-124 (pp. 83-92).

19 The annotations in Greek and Latin papyri from Egypt were studied in Kathleen McNamee, Annotations in Greek and Latin Texts from Egypt, American Studies in Papyrology, 45 (Oakville, Conn.: American Society of Papyrologists, 2007). The essential work on the annotation symbols used in papyri remains Kathleen McNamee, Sigla and Select Marginalia in Greek. Literary Papyri, Papyrologica Bruxellensi, 26 (Bruxelles: Fondation Égyptologique Reine Élisabeth, 1992). The most recent examination of the subject was carried out in Signes Dans Les Textes, Textes Sur Les Signes Érudition, Lecture et Écriture Dans Le Monde Gréco-Romain., ed. by Gabriel Macedo and Maria Chiara Scappaticcio (Liège: Presses Universitaires de Liège, 2017). 
predominantly Greek not Latin texts. The papyri therefore reflect the scribal practices of the Greek instead of the Latin world. However, it can be noted that the annotation symbols found in those papyri from Herculaneum that have been examined to date resemble contemporary Greek signs, rather than representing specific Western types. ${ }^{20}$ The ancient Greek conventions therefore seem to have been used in the Latin West as well. This is also evidenced by the fact that some ancient Greek conventions survived in Western scribal practices into the early Middle Ages, showing a remarkable degree of continuity from Hellenistic and Roman times.

An excellent example is a z-shaped siglum that presumably stands for $\zeta \dot{\eta} \tau \varepsilon \iota$ (Gr. 'look up! search!'). ${ }^{21}$ This query sign can be found in Greek papyri from the first century CE onwards. ${ }^{22}$ While it was used in several different capacities in Antiquity (for example, as a sign marking debtors in the documentary papyrus P. Flor. 71), one function stands out: it was also used to mark lines or verses in need of correction. ${ }^{23}$ This usage of the $\zeta \dot{\eta} \tau \varepsilon \iota$ is documented, for example, in second-century fragments of Sophocles (P. Oxy.ix 1174) and Epicharmus (P. Oxy. xxv 2429). ${ }^{24}$ The same sign can be encountered in Western manuscripts from the fifth century onwards, that is from the oldest period from which we have substantial Western manuscript evidence. ${ }^{25}$ As the manuscripts attest, the usage of $\zeta \dot{\eta} \tau \varepsilon \iota$ continued uninterrupted through the sixth and seventh century well into the eighth. ${ }^{26}$ At the end of

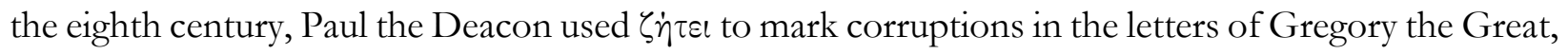
calling it a vitii signum: the only written testimony referring to this sign. ${ }^{27}$ Italy, Paul's homeland, was in

${ }^{20}$ An overview of the annotation symbols found in the Greek papyri from Herculaneum is provided in Guglielmo Cavallo, Libri scritture scribi a Ercolano: introduzione allo studio dei materiali greci, Cronache Ercolanesi, 13 (Naples: Macchiaroli, 1983), pp. 23-25. It can, of course, be argued that although the Greek papyri from Herculaneum are of Western provenance, they reflect Greek scribal practices because they contain Greek rather than Latin texts. The crucial evidence to support or refute this argument could be provided by the less numerous Latin papyri; however, as they are significantly less well preserved, no survey of their annotation symbols has been conducted to date.

21 An alternative interpretation of this siglum as $\zeta \dot{\eta} \tau \eta \mu \alpha$ (Gr. 'question, inquiry') is provided in August Reifferscheid, 'Mitteilungen aus Handschriften. I. Anecdotum Cavense de notis antiquorum', Rheinisches Museum für Philologie, 23 (1868), 127-33 (p. 131); C. H. Roberts, 'The Antinoë Fragment of Juvenal', The Journal of Egyptian Archaeology, 21.2 (1935), 199209 (p. 202).

22 See Kathleen McNamee, 'Marginalia and Commentaries in Greek Literary Papyri' (unpublished Ph.D. dissertation, Duke University, 1977), pp. 124-25; Eric Gardner Turner, Greek Manuscripts of the Ancient World, Bulletin Supplement, 46, 2nd edn (London: University of London, 1987), p. 16.

${ }^{23}$ The Florentine papyrus is discussed in Albert C. Clark, The Acts of the Apostles (Oxford: Clarendon Press, 1933 ), p. 371.

24 See Turner, p. 66; McNamee, Annotations in Greek and Latin Texts from Egypt, p. 248.

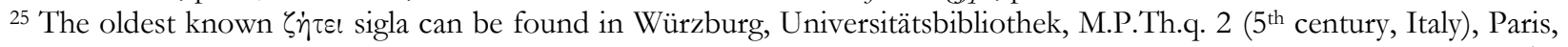
Bibliothèque nationale de France, Lat. 107 ( $5^{\text {th }}$ century), Bologna, Biblioteca Universitaria, MS 701 ( $5^{\text {th }}$ century, 2/2, northern or central Italy), and Vatican, Biblioteca Apostolica Vaticana, Urb. Lat. 1154 (5 ${ }^{\text {th }}$ century, ex.). The Würzburg codex is digitized at: http://vb.uni-wuerzburg.de/ub/mpthq2/pages/mpthq2/116.html (fol. 58v). The Vatican codex is digitized at: http://digi.vatlib.it/view/MSS Urb.lat.1154 (fol. 173v).

${ }^{26}$ This sign is, for example, famously connected to Dulcitius of Aquino, who left a sixth-century subscription in Vienna, Österreichische Nationalbibliothek, P 2160 (6 $6^{\text {th }}$ century, Campania); see Rudolf Beer, Monumenta palaeographica vindobonensia. Denkmäler der Schreibkunst aus der Handschriftensammlung des Habsburg-lothringischen Erzhauses, 2 vols (Vienna: Hiersemann, 1910), I, p. 6. The manuscript is digitized at: http://data.onb.ac.at/rec/AC13950803 (fol. 9v).

${ }^{27}$ See Karl Neff, Die Gedichte des Paulus Diaconus (Munich: Beck, 1908), p. 128: Suscipe tamen quamvis sero epistolas quas desiderasti, et quia mibi eas ante relegere prae occupatione totas non licuit, XXXIIII ex eis scito relectas et prout potui emendatas esse, praeter pauca loca, in quibus minus inveni, et tamen meo ea sensu supplere nolui, ne viderer tanti doctoris verba inmutare; quibus in locis et forinsecus ad aurem

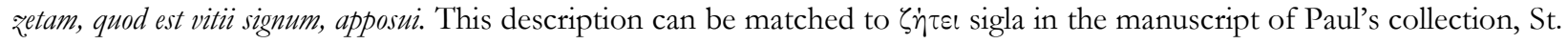
Petersburg, Public Llibrary, F.v.I.7 (c. 787, northern Italy), which, unlike the main text of the manuscript, may have been 
fact one of the places where this ancient siglum continued to be used until the ninth century. ${ }^{28}$ More interestingly, the $\zeta \dot{\eta} \tau \varepsilon l$ was also the preferred form of the correction sign in the insular world, and appears regularly in Irish manuscripts as well as in manuscripts produced in an insular environment on the Continent. ${ }^{29}$ The insular preference for the $\zeta \dot{\eta} \tau \varepsilon \iota$ confirms that in its earliest phase, the insular scribal culture was strongly influenced by ancient models and developed in isolation. ${ }^{30}$ Zì $\tau \varepsilon \iota$ also appears as a correction sign in early medieval Byzantine manuscripts. ${ }^{31}$ The geographically dispersed pattern of its use (Italy, insular world, Byzantium) and its ancient origin suggest that $\zeta \dot{\eta} \tau \varepsilon \iota$ had once been the dominant correction sign across the entire Graeco-Roman world, but must have been replaced by the require siglum in the Latin West at a certain point.

A third corpus of material provides our final data set. The Codices latini antiquiores (CLA) describes the roughly 1900 Latin manuscripts surviving up to the beginning of the ninth century. ${ }^{32}$ While no study like McNamee's systematic examination of annotation in Egyptian papyri exists as yet, the CLA nevertheless occasionally records whether a manuscript contains nota and require signs. It can therefore be used as an indicative list for examining those Western manuscripts that have been digitized. ${ }^{33}$ This examination reveals that the oldest require signs and the oldest nota monograms appear, often together, in the uncial and half-uncial manuscripts of the fifth and sixth centuries. ${ }^{34}$ As noted above, the fifth and the sixth century is when the darkness caused by the lack of Western manuscript evidence is lifted, so the fact that the oldest known nota and require signs appear in codices from this period does not tell us when they first emerged. However, there are several indirect indications that nota and require came

written in Paul's own hand; see Hartmut Hoffmann, 'Autographa des früheren Mittelalters', Deutsches Archiv für Erforschung des Mittelalters, 57 (2001), 1-62 (pp. 17-19).

${ }^{28}$ Examples include Vatican, Biblioteca Apostolica Vaticana, Pal. Lat. 1547 (9 ${ }^{\text {th }}$ century, in., Northern Italy), a manuscript of Seneca's De beneficiis, which was marked with $\zeta \dot{\eta} \tau \varepsilon \iota$ sigla throughout; and Munich, Bayerische Staatsbibliothek, Clm 6375 (9 $9^{\text {th }}$ century, 2/3, northern Italy), a copy of Eusebius's Historia Ecclesiastica. The manuscript of Seneca is digitized at: http://digi.vatlib.it/view/bav pal lat 1547 (fols. 9r-10v). The Eusebius is digitized at: http://daten.digitalesammlungen.de/bsb00054504/image 6 (fol. $2 \mathrm{v}$ ). Lyon, Bibliothèque municipale, MS 483 ( $5^{\text {th }} / 6^{\text {th }}$ century, Italy, CLA VI 779) should also be mentioned. The hand that made the textual annotations in this manuscript, and which has been

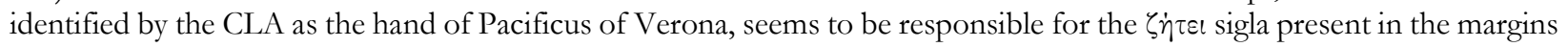
of many pages; see: $\quad$ http://numelyo.bm-

lyon.fr/manuscrits/list.php?order by $=$ Relevance\&cat $=$ quick filter\&search keys $\% 5 \mathrm{Bcore} 8 \% 5 \mathrm{D} \% 5 \mathrm{~B} 0 \% 5 \mathrm{D}=\% 24 \mathrm{colle}$ ction pid\&recherche $=483$ (fol. $73 \mathrm{r}$ ).

${ }^{29}$ See Lindsay, II, p. 12; Clark, pp. 372-73; and most recently Evina Steinová, 'Technical Signs in Early Manuscripts Copied in Irish Minuscule', in The Annotated Book. Early Medieval Practices of Reading and Writing, ed. by Mariken Teeuwen and Irene van Renswoude, Utrecht Studies in Medieval Literacy, 38 (Turnhout: Brepols, 2018), pp. 37-86.

30 See Julian Brown, 'The Oldest Irish Manuscripts and Their Late Antique Background', in Irland Und Europa. Die Kirche Im Frühmittelalter, ed. by Próinséas Ní Chatháin and Michael Richter (Stuttgart: Klett-Cotta, 1984), pp. 311-27.

${ }^{31}$ It features, for example, in Milan, Biblioteca Ambrosiana, E 49 inf. (9 ${ }^{\text {th }}$ century, Byzantium?) and Florence, Biblioteca Medicea Laurenziana, Plut. 32.9 (10 ${ }^{\text {th }}$ century).

${ }^{32}$ E. A. Lowe, Codices Latini Antiquiores: A Palaeographical Guide to Latin Manuscripts Prior to the Ninth Century, 11 vols (Oxford: Clarendon Press, 1934-66). I refer to the CLA numbers in what follows.

33 Nota monograms are recorded in ten CLA items: V 702, VI 802, 804, and 805, VIII 1049 and 1060, X 1443, 1462, 1582, and 1583. Items VI 802 and 805, moreover, record the presence of nota signs in I 104b. Require sigla are mentioned in seven items: II 252, V 563, 632, 633, X 1473, XI 1603, and S 1785.

34 Among the manuscripts containing both signs are: Paris, Bibliothèque nationale de France, Lat. 12214 (6 $6^{\text {th }}$ century, Italy, CLA V 635), and Vatican, Biblioteca Apostolica Vaticana, Vat. Lat. 5757 ( $7^{\text {th }}$ century, Bobbio, CLA I 34). The former is digitized at: http://gallica.bnf.fr/ark:/12148/btv1b105154837/f22 (fol. 6v); the latter at: http://digi.vatlib.it/view/MSS Vat.lat.5757 (p. 101). 
into being relatively late, possibly not much sooner than the oldest surviving manuscripts that contain them.

First, their late appearance on the scene is suggested by their Latin forms. As exemplified by the $\zeta \dot{\eta} \tau \varepsilon \iota$ correction sign, the oldest annotation symbols that are sigla, that is, they are one or two-letter abbreviations of specific commands or exclamations, were derived from the Greek language. This is

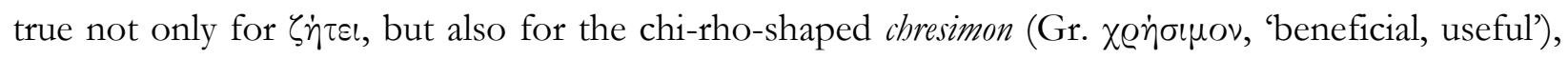

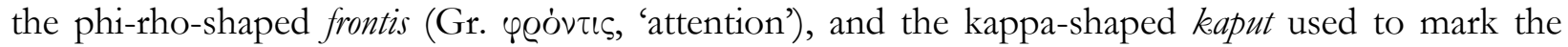

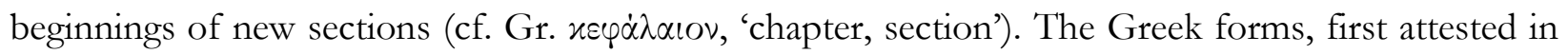
ancient papyri, continued to be used in the Latin West in the Middle Ages. After all, their usage did not demand knowledge of Greek, just the understanding that a specific siglum had a particular purpose. In contrast to the old sigla that were established as scribal conventions in Antiquity, new sigla that came into being in the Latin West in the Middle Ages all have Latin forms. For example, Irish masters marked passages of interest with an l-shaped lectio siglum and a q-shaped quaestio sign. ${ }^{35}$ The nota and require are two of the oldest signs belonging to the new generation of annotation symbols derived from Latin rather than Greek, indicating a break with ancient norms.

Another indication that nota and require emerged relatively late is that their earliest traces in the surviving manuscript evidence correlate with the appearance of two other types of annotation symbols, whose evolution can be more satisfactorily situated in a late antique Western context. The first of these two are omission signs: annotation symbols used to link an incomplete passage in the main text with a supplement in the margins. As E.A. Lowe demonstrated in his seminal article on omission signs, omissions in both Greek and Latin texts were marked with a sign known as the anchora, or with the Greek phrases ö $v \omega$ and $x \dot{\alpha} \tau \omega$ in Antiquity. ${ }^{36}$ The two forms of anchora, $\downarrow$ and $\uparrow$, signalled to the reader whether to look for the supplement to an omission in the upper or the lower margin, respectively. Starting from the fifth century, however, Western scribes began to use omission signs in the form of $h s$ (for bic sursum) and $h d$ (for bic deorsum). E.A. Lowe also noted that the oldest method of citation-marking used in fourth and fifth-century Latin manuscripts was indentation, a practice that has its origin in ancient book workshops and was a characteristic of ancient papyri. ${ }^{37} \mathrm{~A}$ recent survey of the CLA has shown that a rapid transformation took place between the fifth and the sixth centuries, the indentation falling out of use and giving way to citation-marking by means of annotation symbols such as the diple and its cursive form, the S-shaped flourish. ${ }^{38}$ The nota and require seem, therefore, to have been part and parcel of a major change in annotation practices in the Latin West, itself one of the chapters in the transformation of the book between Antiquity and the Middle Ages. ${ }^{39}$

\footnotetext{
35 See Steinová, 'Technical Signs in Early Manuscripts Copied in Irish Minuscule', p. 46 and 53.

${ }^{36}$ Elias Avery Lowe, 'The Oldest Omission Signs in Latin Manuscripts: Their Origin and Significance', in Miscellanea Giovanni Mercati, Studi e Testi, 126 (Vatican: Biblioteca Apostolica Vaticana, 1946), IV, 36-79.

37 E. A. Lowe, 'More Facts about Our Oldest Latin Manuscripts', in Palaeographical Papers, ed. by Ludwig Bieler, 2 vols (Oxford: Clarendon Press, 1972), I, 251-74 (p. 273).

38 Steinová, 'The Rise of the Quotation Sign in the Latin West and the Changing Modes of Reading between the Sixth and the Ninth Centuries'.

${ }^{39}$ One of the seminal studies of this transformation is Armando Petrucci, 'La concezione cristiana del libro fra VI e VII secolo', in Scrivere e leggere nell'Italia medievale (Milan: Sylvestre Bonnard, 2007), pp. 43-64. Currently, Jesse Keskiaho is preparing a book analyzing the transformation of annotation practices in Late Antiquity.
} 
A third indication that nota and require developed in Late Antiquity, perhaps as late as the fifth and sixth centuries - the date of our oldest evidence of their usage - is also the most intriguing and difficult to interpret. When studying the annotation symbols employed in late antique books, one cannot avoid noticing a peculiar 'mirroring' between the Greek conventions and their Latin counterparts. The three most important sign types with Latin forms - nota and require signs discussed here, and the omission signs hic sursum and bic deorsum studied by Lowe, all attested for the first time in fifth-century manuscripts - look like translations of sigla found in older Greek papyri or codices. The Latin siglum require seems to be a rendering of the Greek $\zeta \dot{\eta} \tau \varepsilon .^{40}$ Similarly, sursum and deorsum, as Lowe pointed out, correspond to the earlier Greek óv $\omega$ and $x \dot{\alpha} \tau \omega .{ }^{41}$ Finally, the Latin nota has a parallel in the Greek imperative $\sigma \eta \mu \varepsilon i \omega \sigma \alpha$, an attention siglum found in Greek manuscripts from at least the fourth century. ${ }^{42}$ Given its significance, the latter case requires closer attention.

Unlike the $\zeta \dot{\eta} \tau \varepsilon \iota$ query signs and the ancient omission signs, the $\sigma \eta \mu \varepsilon i \omega \sigma \alpha \iota$ does not seem to be of ancient origin and does not appear in Classical texts. Rather, this attention sign can be found for the first time in the margins of late antique legal manuscripts and Christian texts. Among the oldest witnesses of its usage are the Codex Vaticanus and the Scholia Sinaitica. ${ }^{43}$ The appearance of the $\sigma \eta \mu \varepsilon i \omega \sigma \alpha \iota$ in legal manuscripts, as a fully written exclamation in the margins, in the abbreviated form $\sigma \eta \mu$, and as a siglum in the form of sigma with superscript eta, may have its roots in the specific character of legal training in Late Antiquity. The law was written down in Latin and required the denizens of the Eastern provinces of the Empire to acquire a basic comprehension of the language of the Western provinces, effectively the only context in which Greek speakers had to familiarize themselves with Latin. Unsurprisingly, a whole set of new tools emerged in the context of the study of law to aid students to find their way through the Latin. ${ }^{44}$ The $\sigma \eta \mu \varepsilon i \omega \sigma \alpha l$ was one of several annotation symbols that have their origin in this context and that were later placed at the service of Christian users, a sure sign that the two communities overlapped. ${ }^{45}$ If, indeed, the nota monogram is a Western derivate of the $\sigma \eta \mu \varepsilon i \omega \sigma \alpha \iota$ siglum, the Latin sign must be a late antique creation. By extension, it is reasonable to assume this is true for the require correction sign and the hic sursum and hic deorsum omission signs, which are connected with the nota monogram in the manuscript evidence.

\footnotetext{
40 The only scholar to have noted the similarity, to my knowledge, was Aloys Kehl, see Aloys Kehl, Der Psalmenkommentar von Tura, Quaternio IX (Pap. Colon. theol. 1), Papyrologica Coloniensia, 1 (Cologne: Westdeutscher Verlag, 1964), p. 23.

${ }^{41}$ Lowe, IV, p. 77.

${ }^{42}$ For this siglum, see Henry Barclay Swete, An Introduction to the Old Testament in Greek: With an Appendix Containing the Letter of Aristeas, ed. by Richard Rusden Ottley (New York: Ktav Publishing House, 1968), p. 365; McNamee, Annotations in Greek and Latin Texts from Egypt, p. 123.

${ }^{43}$ See McNamee, Annotations in Greek and Latin Texts from Egypt, p. 20; Marcus Stein, 'Kritische Zeichen', Das Reallexikon für Antike und Christentum (Stuttgart: Hiersemann, 2008), 133-63 (p. 160).

${ }^{44}$ See Kathleen McNamee, 'Another Chapter in the History of Scholia', The Classical Quarterly, 48.1 (1998), 269-288; Simon Corcoran, 'Roman Law and the Two Languages in Justinian's Empire', Bulletin of the Institute of Classical Studies, 60.1 (2017), 96-116.

45 The most important example of the Christian adoption of those annotation symbols that emerged in this legal context are the so-called Scholia Alexandrina to the Orationes of Gregory of Nazianzus. The scholiast, whose floruit was dated to the sixth century, combined textual commentary with annotation symbols, including the $\sigma \eta \mu \varepsilon i \omega \sigma \alpha l$ siglum. The scholia include a prefatory list of annotation symbols, which contains the only written description of the $\sigma \eta \mu \varepsilon i \omega \sigma \alpha \iota$; see Charles Astruc, 'Remarques sur les signes marginaux de certains manuscrits de S. Grégoire de Nazianze', Analecta Bollandiana, 92.1-2 (1974), 289-95 (p. 290).
} 
These are not all of the implication of the 'mirroring'. If the Latin sigla came into being as a reflection of Greek conventions, we must assume that whoever invented them was familiar with ancient and contemporary Greek annotation practices and chose to transfer them from the Greek context to the Latin. Was it perhaps for the benefit of those Western book users who could no longer be expected to be familiar with Greek practices? Or is the emergence of the three sigla a result of a conscious break with older Greek models in the Latin West?

\section{The ancient and medieval forms of the nota and require}

Now that we have seen that two of the most important Western medieval annotation symbols came into being in Late Antiquity, it is essential to highlight the difference between their late antique and medieval forms, which points to a difference in their usage and embedding in annotation practices.

The oldest nota signs that can be found in Western manuscripts represent variations on a single graphic type. This type has the form of an uncial $\mathrm{N}$ with a superscripted $\mathrm{O}\left(\mathrm{N}^{\mathrm{O}}\right.$-type), or, less commonly, the superscript $\mathrm{O}$ appears above an $\mathrm{NT}$ nexus $\left(\mathrm{NT}^{\mathrm{O}}\right.$-type). The first minim often descends below the baseline, and like contemporary annotations, the sign may slant to the right. (see Plate 1). This is the graphic form that appears, for example, in Vienna, Österreichische Nationalbibliothek, P $2160\left(6^{\text {th }}\right.$ century, Campania, CLA X 1507, $\mathrm{N}^{\mathrm{O}}$-type), Vatican, Biblioteca Apostolica Vaticana, Reg. Lat. 886 (6 ${ }^{\text {th }}$ century, France, CLA I 110, $\mathrm{N}^{\mathrm{O}}$-type), Paris, Bibliothèque nationale de France, Lat. 12214 ( $6^{\text {th }}$ century, Italy, CLA V 635, both $\mathrm{N}^{\mathrm{O}}$ - and $\mathrm{NT}^{\mathrm{O}}$-type), and Vatican, Archivio di s. Pietro, D 182 (c. 510, Calgiari, southern Italy, CLA I 1, $\mathrm{NT}^{\mathrm{O}}$-type). This ancient form of nota sign is almost entirely absent from the manuscripts of the eighth and the ninth centuries. By contrast, the standard Carolingian nota sign has the form based on the NT nexus (NT-type). If present, the $\mathrm{O}$ merges with the second minim of $\mathrm{N}$ and the ascender of T (NoT-type, see Plate 2). Occasionally, the A (minuscule or majuscule) hangs from the second minim of $\mathrm{N}$ (NTa- and NoTa-type). A minuscule or majuscule $\mathrm{N}$ is also occasionally used as a nota sign in the Carolingian period (N-type).

The require siglum has similarly distinct ancient and early medieval forms. The ancient form of the require, which is the only form present as a contemporary addition in late antique manuscripts, resembles the uncial or the rustic capital $\mathrm{R}$ crossed with a long transversal stroke traced from the upper right to the lower left corner through the intersection of the bow and the legs of the $\mathrm{R}$ (see Plate 3 ). This form can be found, among others, in Paris, Bibliothèque nationale de France, Lat. 6400B (5 ${ }^{\text {th }}$ century, Italy, CLA V 563), Lyon, Bibliothèque de la Ville, MS $452\left(5^{\text {th }}\right.$ century, ex., perhaps Italy and Lyons, CLA VI 775), and Vatican, Biblioteca Apostolica Vaticana, Lat. 3375 (6 ${ }^{\text {th }}$ century, southern Italy, CLA I 16). ${ }^{46}$ By contrast, the forms of require in early medieval manuscripts either do not have any transversal stroke, or if they have it, the stroke crosses only the right leg of R. The most common graphic variant of the require siglum in the Carolingian period is the minuscule $\mathrm{r}$ (see Plate 4). Other

\footnotetext{
46 The same siglum can also be found in contemporary papyri containing legal texts, such as P. Ant. 153 (5 th century,

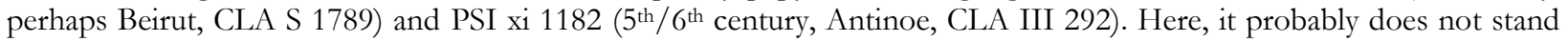
for require; rather, the siglum should be resolved as responsum. See McNamee, Annotations in Greek and Latin Texts from Egypt, p. 493 and 508-11. The latter is digitized at: http://www.accademiafiorentina.it/paplett/scheda.asp?id=264 (side D)
} 
graphic variants of the siglum include minuscule and majuscule $\mathrm{r}$ with a superimposed stroke, and the two-letter form rq, as wells forms which utilize $\mathrm{q}$ and $\mathrm{qr}$ (for quaere) ${ }^{47}$ While there is more diversity in the forms of the require sign in the early Middle Ages than in Late Antiquity, as with the nota sign, the ancient form of the siglum does not recur in early medieval manuscripts.

The tangible differences in the form of the two signs in Late Antiquity and the early Middle Ages are particularly useful to paleographers. They allow us to discern when a late antique manuscript was annotated by a contemporary hand and when it was annotated by a later reader. ${ }^{48}$ Since many late antique manuscripts carry no other marginalia than the annotation symbols, and since the use of annotation symbols was particularly widespread in the early medieval period, the presence of distinctly medieval forms of signs, especially if many different types are found in a single manuscript, is a good indicator that the book was read in the medieval period. Furthermore, the opposite phenomenon can also be observed, as manuscripts produced in early medieval scripts occasionally contain nota monograms that look like imitations of the ancient nota form (although never the ancient require siglum). These ancient-looking nota signs are obviously the work of medieval annotators. They may indicate that the manuscript was copied from a late antique exemplar that was equipped with nota monograms, especially if it contains textual marginalia that may be reasonably suspected to be late antique in origin and therefore carried over in their entirety. ${ }^{49}$ Another possibility is that early medieval readers in centres that possessed late antique manuscripts drew on these manuscripts for inspiration, just as ancient codices may have served as models for other aspects of early medieval book culture. ${ }^{50}$ The ancient form of the nota can be encountered in particular in manuscripts associated with Fleury, where it may have been re-introduced by Visigothic visitors. ${ }^{51}$

\footnotetext{
${ }^{47}$ See Lindsay, II, p. 12; Birger Munk Olsen, L'étude des auteurs classiques latins aux XIe et XIIe siècles, Documents, études et répertoires publiés par l'Institut de Recherche et d'Histoire des Textes (Paris: CNRS Éditions, 2009), 4.1, p. 287.

48 Thus, the require sigla in Rome, Biblioteca Nazionale, Sessoriano 13 ( $6^{\text {th }}$ century, $1 / 2$, Italy, CLA IV 418) can be interpreted as a trace of the activity of the ninth-century annotator. The sixth-century copyist seems to have used the cryphia as their

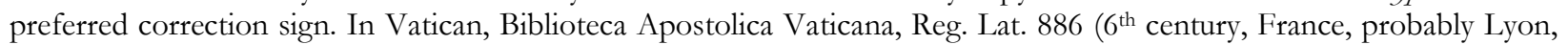
CLA I 110), the nota monograms seem to have been entered by a near-contemporary hand, but the require signs by an early medieval user. The contemporary corrector used the $\zeta \dot{\eta} \tau \varepsilon \iota$ instead. The manuscript is digitized at: http://digi.vatlib.it/view/MSS Reg.lat.886 (fol. 58v). In Vatican, Biblioteca Apostolica Vaticana, Lat. 3375 (6 ${ }^{\text {th }}$ century, southern Italy, CLA I 16), the require sigla are contemporary with the main text, but the single nota on fol. 20r seems to have been added in the ninth century. The manuscript is digitized at: https://digi.vatlib.it/view/MSS Vat.lat.3375/0051 (fol. 20r).

49 This seems to be case of Paris, Bibliothèque nationale de France, Lat. 2706 ( ( $^{\text {th }}$ century, in., East Francia, CLA V 547), a manuscript of Augustine's De Genesi ad litteram containing a set of annotations of late antique origin, see Jesse Keskiaho, 'A Widespread Set of Late-Antique Annotations to Augustine's “De Genesi Ad Litteram"', Sacris Erudiri, 55 (2016), $79-$ 128. The manuscript is digitized at: http://gallica.bnf.fr/ark:/12148/btv1b10033740x/f162 (fol. 159v).

${ }^{50}$ See Rosamond McKitterick, 'Glossaries and Other Innovations in Carolingian Book Production', in Turning over a New Leaf: Change and Development in the Medieval Book, ed. by Rosamond McKitterick, Erik Kwakkel, and Rodney Thomson (Leiden: Leiden University Press, 2012), pp. 21-193. This may have be the case at Reims, where the ancient form of the nota monogram is found in Vatican, Biblioteca Apostolica Vaticana, Reg. Lat. 201 (9th century, 3/4, perhaps Reims). The manuscript is digitized at: http://digi.vatlib.it/view/MSS Reg.lat.201 (fol. 24r).

${ }^{51}$ In Vatican, Biblioteca Apostolica Vaticana, Reg. Lat. 267 (6 $6^{\text {th }}$ century, ex., perhaps France, CLA I 104), a manuscript kept in the ninth century at Fleury, the nota monograms were added by a ninth-century hand that also added annotations in Visigothic minuscule throughout. The manuscript is digitized at: https://digi.vatlib.it/view/MSS Reg.lat.267/0036 (fol. 16v). Nota signs resembling the ancient form can be also found in other manuscripts kept at Fleury in the ninth century,
} 


\section{Comparison with quotation signs}

A detailed study of the graphic variants of nota and require signs, to see whether particular regions or centres display a preference for a particular variant - as seems to have been the case at Fleury - would certainly be valuable. Unfortunately, the fragmentary preservation of Western manuscripts prior to 800 means that any attempt at a reconstruction of the development of nota and require signs between the fifth and ninth centuries can meet only with partial success. As for the following centuries, scholarship on this subject will depend on ongoing digitization efforts, especially since annotation symbols can be easily harvested and pre-assessed with the aid of digital technologies. We will probably never know whether nota and require originated in a particular scholarly circle or region, or whether their eventual success can be connected with the transmission of certain texts, or the influence of important agents, centres or intellectual milieus. It is equally difficult to assess when and how nota and require transformed from signs of local importance and limited popularity to, respectively, the dominant forms of attention and correction signs that overshadowed other conventions, a situation that is indicated by Carolingian manuscripts. Nevertheless, there exist promising avenues of research. Quotation signs, which seem to belong to the same set of scribal practices as the nota and require signs, and for which both continuous and robust paleographic evidence exists from before 800, can provide us with a useful model against which to assess the rise of the new Western type of attention and correction sign.

To examine this in more detail, let us return for the last time to the CLA. The eleven volumes of this catalogue record the presence of citation-markers in more than 300 manuscripts, that is over $16 \%$ of surviving pre- 800 codices. ${ }^{52}$ While the manuscripts that survive from before the beginning of the ninth century are not necessarily a random set, the insertion of quotation signs itself does not seem to have affected the survival of manuscripts and gives us a rough idea of their patterns of usage. ${ }^{53}$ The data collected in the CLA reveal that about $13 \%$ of surviving fifth-century Western manuscripts were equipped with citation marks, chiefly in the form of indentation, as noted by Lowe. Even though quotation signs replaced indentation as the primary method of marking quotations in the Latin West from the sixth century onwards, the proportion of surviving manuscripts bearing citation marks remained below $20 \%$ until the beginning of the ninth century. However, according to the data gathered from the early medieval Bavarian manuscripts, more than $60 \%$ of codices from this region contain quotation signs. If the ratios observed in early medieval Bavaria can be extended to the Carolingian period as a whole, a sharp increase in citation-marking seems to have taken place shortly after 800. It cannot be explained simply as a distortion caused by the uneven manuscript survival rate,

such as Orléans, Bibliothèque municipale, MS 154 ( $8^{\text {th }}$ century, med., France, CLA VI 802) and Orléans, Bibliothèque municipale, MS 192 (6 $6^{\text {th }} / 7^{\text {th }}$ century, southern France, CLA VI 805).

52 The following data are taken from Steinová, 'The Rise of the Quotation Sign in the Latin West and the Changing Modes of Reading between the Sixth and the Ninth Centuries'.

53 The only significant concern may be the correlation between the presence of textual annotations and quotation signs in pre-800 manuscripts, as it seems that the presence of textual annotations correlates with the survival of late antique manuscripts; see the forthcoming work of Jesse Keskiaho. 
especially as a qualitative change can also be observed: S-shaped quotation signs represent more than $90 \%$ of quotation signs in the Bavarian corpus, while until the eighth century, their ratio in the surviving manuscript containing citation marks does not seem to have reached $50 \% .^{54}$

This pattern of distribution in CLA manuscripts and in the Bavarian corpus suggests that S-shaped flourishes attained a dominant position only in the Carolingian period, possibly once this form of the quotation sign became favoured by the users of Caroline minuscule and became associated with this script. Of course, the pattern of distribution of quotation signs cannot be taken automatically to represent how nota and require signs developed. The quotation signs marked citations that were inserted in the text by an author and were therefore definite in number and position, while nota attention signs reflected that which aroused the curiosity of readers, and require correction signs marked features generated by the transmission process. Nevertheless, at the chronological end-point of this examination, in the Carolingian period, these signs seem to have acquired a similar status among the users of Caroline minuscule as S-shaped flourishes. We have seen this from the example of Bavarian manuscripts. The nota attention sign, the require correction sign, and the S-shaped quotation sign had therefore attained a similar status by the Carolingian period, if not in late Antiquity. This trio of signs can therefore be seen as a standard set, implying that they were known even to users who possessed modest erudition.

That nota and require would become the prevailing form of attention and correction signs in the medieval West - a primacy that only solidified further in the centuries after the Carolingian period was in no way self-evident in the earlier period, nor can we observe a clear trajectory towards a uniformization of annotation practices before the Carolingian times. Nota monograms and require sigla were late arrivals. When they first appeared, manuscript margins were already populated by other annotation symbols, many of which also served as attention or correction signs. Errors in late antique

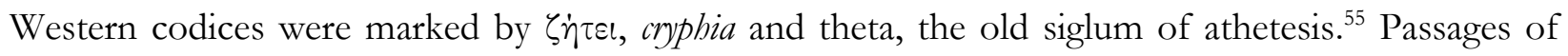
interest could be highlighted by the chresimon, a staurogram-like symbol ( $f$ ) and an M-shaped siglum, presumably standing for mire. ${ }^{56}$ Indeed, the margins of fifth- and sixth-century manuscripts provide a

\footnotetext{
${ }^{54}$ On other indications that suggest a conscious promotion of citation-marking and the use of S-shaped flourishes for this purpose, see Steinová, 'The Rise of the Quotation Sign in the Latin West and the Changing Modes of Reading between the Sixth and the Ninth Centuries'.

55 To give just a few further examples of $\zeta \dot{\eta} \tau \varepsilon \iota$ in Western manuscripts it was used by the correctors of Vatican, Biblioteca Apostolica Vaticana, Reg. Lat. 267 ( $6^{\text {th }}$ century, ex., perhaps France, CLA I 104) and Vatican, Biblioteca Apostolica Vaticana, Pal. Lat. 210 ( $6^{\text {th }}$ century, in., Italy, CLA I 84). The cryphia is found in Paris, Bibliothèque nationale de France, Lat. 2235 ( $6^{\text {th }}$ century, Italy, CLA V 543), and in Florence, Biblioteca Medicea Laurenziana, Plut. 65.1 ( $6^{\text {th }}$ century, perhaps Ravenna, CLA III 298). In the latter, the sign is accompanied by the note non est sensus in hoc loco. See at: http://teca.bmlonline.it/ImageViewer/servlet/ImageViewer?idr=TECA0000767441\#page/1/mode/1up (fol. 35v). The theta makes an appearance in the Medicean Virgil, Florence, Biblioteca Medicea Laurenziana, Plut. 39.1 (5 $5^{\text {th }}$ century, Rome, CLA III 296), and in Fulda, Landesbibliothek, Bonifatianus I (c. 546, Capua, CLA VIII 1196), the New Testament codex emended famously by Victor of Capua. The former is digitized at: http://www.internetculturale.it/opencms/opencms/it/viewItemMag.jsp?case=\&id=oai $\% 3 \mathrm{Ateca} \cdot \mathrm{bmlonline.it} \% 3 \mathrm{~A} 21 \% 3$ AXXXX $\% 3$ APlutei $\% 3 A I T \% 253$ AFI0100 Plutei 39.01 (fol. 31v); the latter at: http://fuldig.hsfulda.de/viewer/image/PPN325289808/1/LOG 0000/ (fol. 51v).

${ }^{56}$ To give just a few examples of many, the staurogram-like attention sign is found in St. Gallen, Stiftsbibliothek, MS 1395 $\left(5^{\text {th }}\right.$ century, $1 / 2$, Italy, CLA VII 984), Paris, Bibliothèque nationale de France, Lat. 8907 ( $5^{\text {th }} / 6^{\text {th }}$ century, northern Italy, CLA V 572), and Vatican, Archivio di s. Pietro, D 182 (c. 510, Calgiari, southern Italy, CLA I 1). The St. Gallen manuscript is digitized at: http://www.e-codices.unifr.ch/en/csg/1395/135/0/Sequence-749 (p. 135). The Parisian manuscript is
} 
picture significantly more heterogeneous than those of Carolingian manuscripts from the Bavarian corpus. No single convention or set of conventions seems to have been universally preferred. Nevertheless, it was nota and require (as well as the S-shaped flourish, but not the bic sursum and bic deorsum omission signs) that monopolized the margin in the early medieval West. Was this a result of choices made by Carolingian masters, who so loved order and standardization, at the end of the eighth century? Or was the road to the rise of the nota and require signs laid out in the preceding two centuries, as it seems that some Merovingian scriptoria preferred the two annotation symbols from early on? Or should the roots of the dissemination of the two signs be sought at the very beginning, in the fact that nota, require, the S-shaped quotation signs and the bic sursum and hic deorsum may have been conceived as a set? There is probably a grain of truth in all three scenarios.

\section{Conclusion}

In this article, I have presented different types of paleographic evidence to chart the history of two familiar Western annotation symbols used in the Middle Ages. The probing of three manuscript corpora has shown that nota and require signs emerged in Late Antiquity, certainly by the fifth century and possibly already in the fourth. It is also quite probable that the two signs appeared in the same context as one or two other conventions. With the exception of quotation signs, what characterizes these new late antique conventions is that they are derived from the Latin rather than the Greek language. While some of the annotation symbols encountered in medieval Western manuscripts are ancient in origin and reflect the first notable wave of annotation practices in the Hellenistic and Roman period, nota and require reflect the second wave of convention-formation, one that took place at the same time in the Greek East and Latin West in post-Classical times ${ }^{57}$ It is possible that further research will reveal that nota and require signs can be traced back to a particular circle or centre of bookproduction. At present, one thing is clear: the new conventions should be connected with the Christian milieu, as they are found, with only a few exceptions, attached to Patristic texts. ${ }^{58}$ Classical texts from the same period are either devoid of annotation symbols, or contain vestiges of ancient annotation practices. ${ }^{59}$ It should not surprise us that they reflect the dying world of textual scholarship that originated in Hellenistic Alexandria and was cultivated by Roman scholars such as Varro or Valerius Probus, just as the new conventions appear in manuscripts that represent the ascending world of

digitized at: http://gallica.bnf.fr/ark:/12148/btv1b105450163/f693 (fol. 342r). The M-shaped siglum appears in Bologna, Biblioteca Universitaria, MS 701 ( $5^{\text {th }}$ century, 2/2, northern or central Italy, CLA III 280).

57 This article only discusses Western annotation symbols, but new conventions also emerged in the Greek environment; see Kathleen McNamee, 'Sigla in Late Greek Literary Papyri', in Signes Dans Les Textes, Textes Sur Les Signes: Érudition, Lecture et Écriture Dans Le Monde Gréco-Romain, Papyrologica Leodiensia, 6 (Leuven: Leuven University Press, 2017), pp. $127-41$.

58 Among the few exceptions are the Bembine Terence, Vatican, Biblioteca Apostolica Vaticana, Lat. $3226\left(4^{\text {th }} / 5^{\text {th }}\right.$ century, Italy, CLA I 12), in which a single ancient require appears in the inner margin on fol. 87r, and the Medicean Virgil, Florence, Biblioteca Medicea Laurenziana, Plut. 39.1 ( $5^{\text {th }}$ century, Rome), which contains the ancient form of the nota monogram on ten pages. The former is digitized at: http://digi.vatlib.it/view/MSS Vat.lat.3226 (fol. 87r).

59 See Marcus Deufert, 'Overlooked Manuscript Evidence for Interpolations in Lucretius?', in Latin Literature and Its Transmission, ed. by Richard Hunter and S. P. Oakley, Cambridge Classical Studies (Cambridge: Cambridge University Press, 2015), pp. 68-87. The emptiness of the margins of late antique Classical Latin codices is striking in comparison both with contemporary Christian Latin codices and Classical Greek papyri. 
Christian scholarship with its particular concerns and pursuits. ${ }^{60}$ The newly instituted quotation signs were therefore not meant to mark just any citations, but specifically those coming from the Bible, and the nota monograms often highlight points relevant to Christian audiences. By the Carolingian period, nota and require became the staple annotation tools of ordinary readers, even half-literate monks and clerics; but at the beginning of their existence, they may have had a more specific purpose as a powerful tool for new types of reading and inquiry in certain learned Christian circles. The oldest chapter in the history of the two annotation symbols may be overshadowed by their medieval proliferation, but it mustn't be overlooked, especially since recent scholarship has increasingly emphasized the richness of the late antique Christian annotation culture and its influence on early medieval scribal practices. ${ }^{61}$

The study of the various forms of nota and require signs is not just a scholarly exercise, but has a practical value, especially given how commonly the two signs appear in manuscript evidence. We can learn much from them, once we understand their distribution patterns and regionalized variants. As we can now distinguish the ancient and the medieval form of nota and require signs, it will perhaps become possible to identify forms characteristic of certain regions, centres and perhaps even scholarly circles and individuals. Furthermore, these two signs have the power to provide us with a large-scale picture of how books were read in the Latin West. The nota monograms, which should be considered readers' signs rather than the signs of copyists or correctors, are particularly valuable for tracing readers' habits and interests, even in cases when those readers did not leave a trace in the form of their own literary production or textual annotations.

${ }^{60}$ For the Roman scholars using annotation symbols, see H. D. Jocelyn, 'The Annotations of M. Valerivs Probvs (I)', The Classical Quarterly (New Series), 34.2 (1984), 464-472; H. D. Jocelyn, 'The Annotations of M. Valerivs Probvs (II)', The Classical Quarterly, 35.1 (1985), 149-161; H. D. Jocelyn, 'The Annotations of M. Valerivs Probvs, III: Some Virgilian Scholia', The Classical Quarterly, 35.2 (1985), 466-474.

61 See Richard M. Pollard, 'Reading Josephus at Vivarium? Annotations and Exegesis in Early Copies of the Antiquities', Florilegium, 30 (2013), 103-42; Warren Pezé, 'Des notes marginales sur le schisme des Trois Chapitres dans le plus vieux manuscrit du De baptismo contra donatistas', Revue d'études augustiniennes et patristiques, 62 (2016), 293-334; Jesse Keskiaho, 'The Annotation of Patristic Texts as Curatorial Activity?: The Case of Marginalia to Augustine's De Genesi Ad Litteram in Late Antiquity and the Early Middle Ages', in The Annotated Book. Early Medieval Practices of Reading and Writing, ed. by Mariken Teeuwen and Irene van Renswoude, Utrecht Studies in Medieval Literacy, 38 (Turnhout: Brepols, 2018). 


\section{Images}

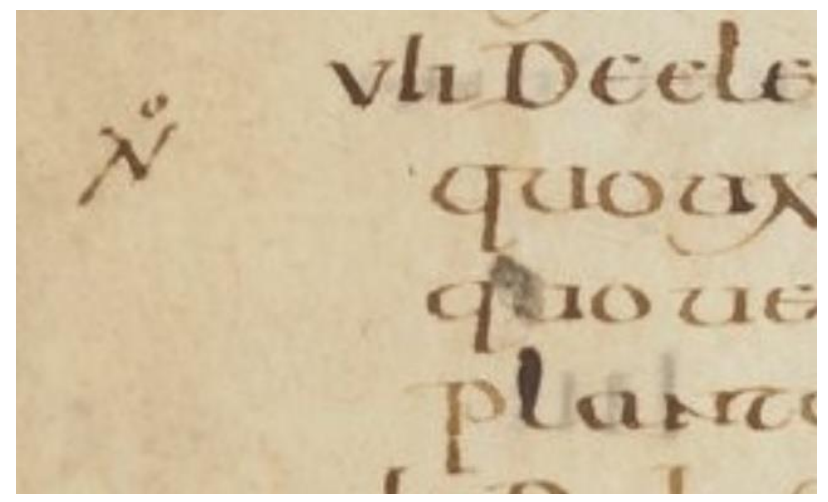

Plate 1 Paris, Bibliothèque nationale de France, Lat. 12214, fol. 6v

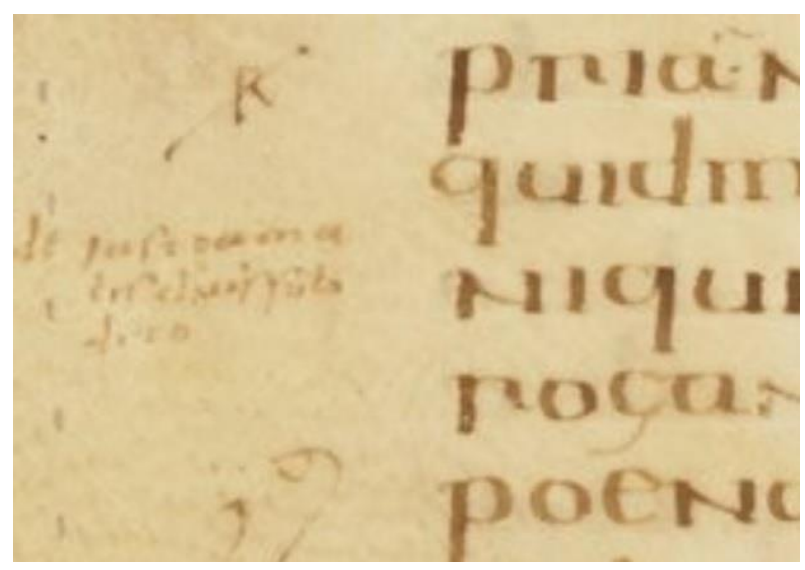

Plate 3 Paris, Bibliothèque nationale de France, Lat. 12214, fol. 111v
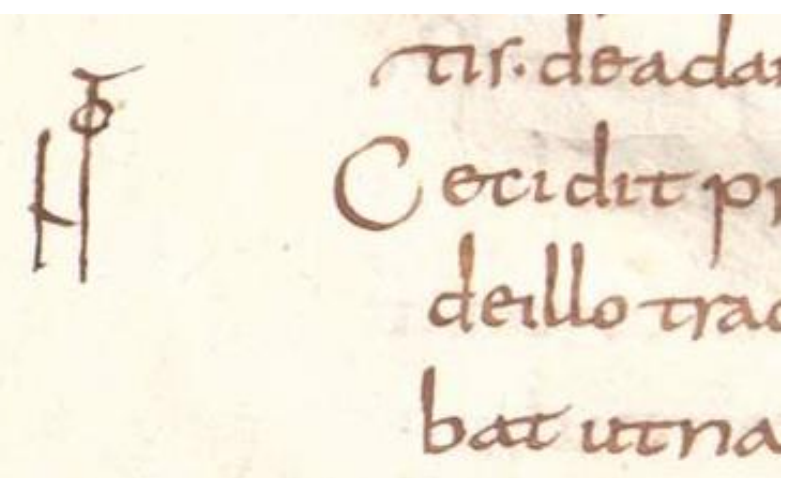

Plate 1 Munich, Bayerische Staatsbibliothek, Clm 6287, fol. 28v

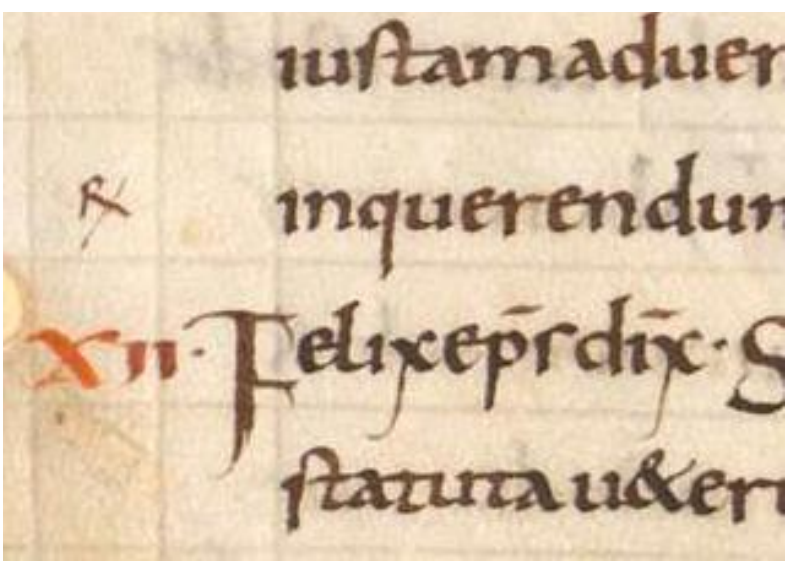

Plate 4 Munich, Bayerische Staatsbibliothek, Clm 5508, fol. 20v 